\title{
Electrical insulating liquid: A review
}

\author{
Deba Kumar Mahanta*, ${ }^{\star}$ and Shakuntala Laskar ${ }^{\dagger}$ \\ *Electrical Engineering Department \\ Assam Engineering College, Guwahati 781013, Assam, India \\ ${ }^{\dagger}$ Department of EEE, School of Technology \\ Assam Don Bosco University, Guwahati 781017, Assam, India \\ †debamahanta@gmail.com
}

Received 18 March 2017; Revised 11 June 2017; Accepted 22 June 2017; Published 11 July 2017

\begin{abstract}
Insulating liquid plays an important role for the life span of the transformer. Petroleum-based mineral oil has become dominant insulating liquid of transformer for more than a century for its excellent dielectric and cooling properties. However, the usage of petroleum-based mineral oil, derived from a nonrenewable energy source, has affected the environment for its nonbiodegradability property. Therefore, researchers direct their attention to renewable and biodegradable alternatives. Palm fatty acid ester, coconut oil, sunflower oil, etc. are considered as alternatives to replace mineral oil as transformer insulation liquid. This paper gives an extensive review of different liquid insulating materials used in a transformer. Characterization of different liquids as an insulating material has been discussed. An attempt has been made to classify different insulating liquids-based on different properties.
\end{abstract}

Keywords: Transformer oil; liquid insulation; insulating materials; vegetable oils.

\section{Introduction}

Transformers are key components of electrical power system network. It plays a vital role in every field of power system network like electrical power generation, transmission, and distribution. ${ }^{1}$ The majority of transformers depends on liquid dielectrics as an insulating material. ${ }^{2}$ The classification of insulating liquids are given in Table 1. It prevents internal short circuit, protects the transformer from chemical attack, prevents sludge formation and acts as a cooling agent to remove heat when the transformer is being energized. ${ }^{3,4}$ The mineral oil obtained by fractional distillation and subsequent treatment of crude oil has been used as the liquid insulation for more than 75 years. ${ }^{5,6}$ It is also used in different electrical equipment other than a transformer, which includes different types of high voltage capacitors, ${ }^{7}$ switches, circuit breakers, tap changers and bushings etc. ${ }^{8}$ The purpose of this study is to provide information about different properties of various types of environment-friendly insulating oils which shows potential as regards application in the transformer. This study encouraged researchers to direct their focus onto renewable and biodegradable insulating materials. It reviews the present status of vegetable oils used as insulating and cooling medium in transformer, including their characterization, production, and processing. It shows the main advantages and disadvantages of vegetable oils in comparison with mineral oil giving an outline of the recent research carried out.

\subsection{History of transformer insulating liquid}

In 1892, "General Electric" started the use of first petroleumbased oils as an insulating liquid in the transformer. Commercial production of paraffinic-based mineral oil was started in 1899. Paraffinic-based mineral oil contained large quantity wax resulting undesirable high pour point. It also produced a large amount of insoluble sludge in subzero climate condition which lowered the viscosity and thus reduces heat transfer capacity. Later on paraffinic mineral oil was replaced by naphthenic oils which kept mineral oil as fluid at very low temperature but had the disadvantage of high flammability. Polychlorinated biphenyl (PCB) was first made in 1930, ${ }^{10}$ which overcame the flammability of naphthenic oils. But in early 1970, it was determined that PCB were no longer environmentally acceptable and hence new uses and production of PCBs have been banned. With the termination of the $\mathrm{PCBs}$, the power industries turned to other liquid insulation like synthetic esters, vegetable oil, silicon fluid, etc. ${ }^{11}$ Mineral oil remained the major source among these all. ${ }^{12,13}$

\subsection{Mineral oil as transformer insulating liquid}

The chemical structure of transformer oil is very complex, which is composed of both hydrocarbons and non-hydrocarbons. ${ }^{14}$ Nonhydrocarbon presents in small amount in transformer oil whereas hydrocarbon constitutes the main part containing only carbon and hydrogen. The chemical

\footnotetext{
†Corresponding author.
}

This is an Open Access article published by World Scientific Publishing Company. It is distributed under the terms of the Creative Commons Attribution 4.0 (CC-BY) License. Further distribution of this work is permitted, provided the original work is properly cited. 
Table 1. Classification of insulating liquids.

\begin{tabular}{|c|c|c|}
\hline \multirow[t]{3}{*}{$\begin{array}{l}\text { Mineral insulating } \\
\quad \text { oil }\end{array}$} & Paraffinic oils & $\begin{array}{l}\text { Nonring long-chained } \\
\text { structure }\end{array}$ \\
\hline & Naphthenic oils & Saturated ring structure \\
\hline & Aromatic oils & Nonsaturated ring structure \\
\hline \multirow[t]{3}{*}{$\begin{array}{l}\text { Synthetic } \\
\text { insulating oil }\end{array}$} & Polyalphaolefins & $\begin{array}{l}\text { Manufactured by } \\
\text { polymerization of } \\
\text { hydrocarbon molecules }\end{array}$ \\
\hline & Polyglycols & $\begin{array}{l}\text { Produced by oxidation of } \\
\text { ethylene and propylene }\end{array}$ \\
\hline & Synthetic ester oils & $\begin{array}{l}\text { Produced by reaction of acids } \\
\text { and alcohols with water }\end{array}$ \\
\hline $\begin{array}{l}\text { Vegetable } \\
\quad \text { insulating oil }\end{array}$ & $\begin{array}{l}\text { Soybean oil } \\
\text { Coconut oil } \\
\text { Cottonseed oil } \\
\text { Rapeseed oils }\end{array}$ & $\begin{array}{l}\text { Vegetable oils are nontoxic, } \\
\text { biodegradable, low } \\
\text { inflammable, have a higher } \\
\text { breakdown voltage, high } \\
\text { flash point, high acidity } \\
\text { number, high viscosity and } \\
\text { pour point }\end{array}$ \\
\hline
\end{tabular}

structure of different hydrocarbons present in transformer oil is shown in Fig. 1. Good quality transformer oil contains optimum amount chemical compound. The aromatic compound presence in transformer oil increases the stability of the oil in service while too much of it can reduce the impulse strength or dielectric strength of oil and increase the solvency property of the oil for many of the solid particles immersed in it. Again, presence of sulfur compounds in high concentration causes corrosion of copper in contact with insulating oil. Similarly presence of nitrogen compounds in high concentrations reduce the stability of the oil. The basic properties of transformer oil which are desirable for serving the purpose as dielectric medium and coolant are a high impulse strength, high electric strength, and high volume resistivity, high thermal conductivity, high specific heat, high flash point, low viscosity, low volatility, and low dielectric dissipation factor. Apart from these, good transformer oil should have high resistance to chemical deterioration, nonflammable, cheap and easily available. $^{15}$

\subsection{Alternative to mineral insulating oil}

In recent years, many researchers have been carried out to find out the suitable alternate of transformer oil. ${ }^{16-18}$ Many synthetic, as well as natural fluids have been tested and used as an alternate to the transformer oil. ${ }^{19,20}$ The chemical structure of synthetic ester and the natural ester is shown in Fig. 2. Transformer oil has many disadvantages like presence of polynuclear aromatic hydrocarbons which may readily be released into the environment due to the explosion of a transformer, poor biodegradability and future scarcity. Attention has been paid to vegetable oils like oil from soya beans, sunflower, etc. ${ }^{21,22}$ and synthetic esters as a liquid insulating medium. It has been found in the literature that vegetable oils and synthetic esters have drawn the most attention among all other alternatives of transformer oil. It has properties of low flammability, negligible environmental impact, and high moisture tolerance, nontoxic to aquatic life, high flash point, lower volatility and lower pour point. ${ }^{23,24}$

Aging of vegetable insulating liquids in presence of air leads to oxidation resulting an increase of viscosity. Therefore, it is important to take care during filling the insulating liquid in transformers to exclude oxygen. It shows less thermal aging of insulating paper in it over the temperature range of $70^{\circ} \mathrm{C}$ to $190^{\circ} \mathrm{C}$ compare to the mineral oil. Again, $\mathrm{CO}$ and $\mathrm{CO}_{2}$ concentration are less in aged vegetable oil compared to the aged mineral oil. However, the concentration of water in aged vegetable oil is more when compared to aged mineral oil. Comparison of aging effect on mineral oil and vegetable oil is shown in Table 2.

\subsection{Performance analysis of different insulating liquids}

\subsubsection{Fire and flash point}

Thermal characteristics of both aged and virgin samples of mineral and vegetable oils have been studied in the paper. ${ }^{25}$ It concluded that vegetable oil has better thermal behavior than mineral oil. Palm and coconut oils have safe flash and fire point than mineral oil.

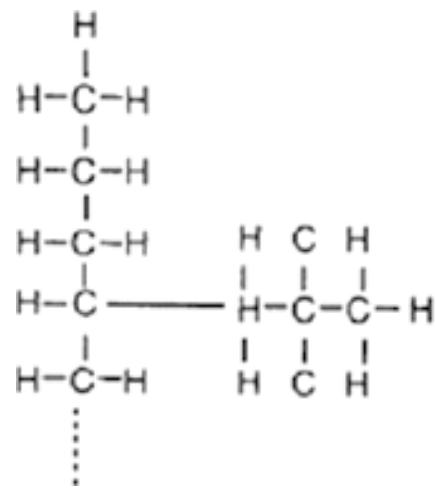

(a) Paraffinic
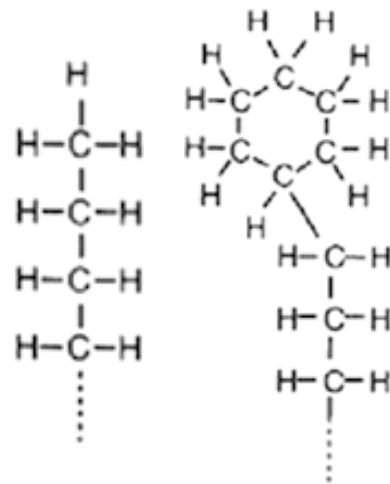

(b) Naphthenic

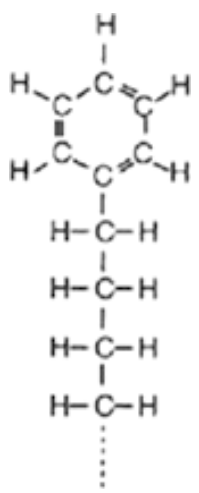

(c) Aromatic

Fig. 1. Chemical structure of different hydrocarbon of mineral oils. 
<smiles>[R]C(=O)OCC(COC([R])=O)(COC([R])=O)COC([R])=O</smiles>

\section{$\mathrm{R}=$ Saturated chain}

(a) Synthetic ester<smiles>[R]C(=O)OCC1COC([R])C([R])OC1</smiles>

\section{R R' R" = Fatty acid chain}

(b) Natural ester
Fig. 2. Chemical structure of synthetic ester and natural ester.

\subsubsection{Arc-quenching property}

The arc-quenching behavior of vegetable oil is high compared to that of mineral oil. It has been found from Ref. 25 that production of acetylene and hydrogen under arcing condition for mineral oil is much more compared to the vegetable oil. But the production of $\mathrm{CO}$ and $\mathrm{CO}_{2}$, due to the breaking of carbonyl group- $\mathrm{COO}$, is much more for vegetable oil in comparison to mineral oil.

\subsubsection{Dielectric breakdown strength}

The dielectric strength, which depends on the moisture in $\mathrm{ppm}$, is better for vegetable oil compared to mineral oil. The effect of moisture on dielectric behavior of ester oil is less compared to that of mineral oil. ${ }^{26}$ Coconut and palm oils have the better dielectric strength than compared with mineral oil.

\subsubsection{Oxidation stability}

Reference 27 explains the experimental study about oxidation stability and found that there was a little change in breakdown

Table 2. Aging properties of insulating liquids. ${ }^{9}$

\begin{tabular}{lllcc}
\hline Property & \multicolumn{1}{c}{ Units } & \multicolumn{1}{c}{ Standards } & Mineral oil & Vegetable oil \\
\hline Viscosity, $40^{\circ} \mathrm{C}$ & $\mathrm{mm}^{2} / \mathrm{s}$ & ISO 3104, ASTM D 445 & 7.6 & 39.2 \\
Density, $20^{\circ} \mathrm{C}$ & $\mathrm{kg} / \mathrm{dm}^{3}$ & ISO 12185, ISO 3675, ASTM D 1298 & 0.877 & 0.9128 \\
Breakdown voltage $(2.5 \mathrm{~mm})$ & $\mathrm{kV}$ & IEC 60156 & $40-60$ & 81 \\
Acidity & $\mathrm{mgKOH} / \mathrm{g}$ & IEC 62021, ASTM D 974 & 0.01 & 0.05 \\
Tan delta $\left(90^{\circ} \mathrm{C}\right.$ and $\left.50 \mathrm{~Hz}\right)$ & - & IEC 60247 & 0.001 & 0.0134 \\
Flash point & ${ }^{\circ} \mathrm{C}$ & ISO 2719, ASTM D 92 & 144 & 332 \\
Moisture content & $\mathrm{mg} / \mathrm{kg}$ & IEC 60814 & $<20$ & 100 \\
\hline
\end{tabular}

Table 3. Deterioration of liquid insulation.

\begin{tabular}{|c|c|c|c|}
\hline Categories & Reasons & Elements & Results \\
\hline \multirow[t]{8}{*}{ Physical contamination } & Solid impurities & Paper & Absorb moisture \\
\hline & & Pressboard & Electrical breakdown \\
\hline & & Wood & Formation of copper soaps \\
\hline & & Varnish & \\
\hline & & Cotton tap & \\
\hline & Foreign matters & Dust & Lowering of electric strength \\
\hline & & Metallic particles & Chemical decomposition of oil \\
\hline & & Fibrous matter & Formation of carbon particles \\
\hline \multirow[t]{4}{*}{ Contamination by gases } & $\begin{array}{l}\text { Dissolved gases in the oil } \\
\text { from atmosphere }\end{array}$ & Breather inhaling & $\begin{array}{l}\text { Lowering the electric strength of the oil due to the } \\
\text { formation of the following gases: }\end{array}$ \\
\hline & $\begin{array}{l}\text { Thermal decomposition of } \\
\text { oil }\end{array}$ & $\begin{array}{l}\text { Decomposition due to arcing } \\
\text { Electrolysis }\end{array}$ & $\begin{array}{l}\text { Methane, Ethane, Ethylene, Acetylene, Propylene, Butane, } \\
\text { Carbon monoxide, Hydrogen, Carbon Dioxide }\end{array}$ \\
\hline & & Vaporization of the oil & \\
\hline & & $\begin{array}{l}\text { Chemical reaction among } \\
\text { different particles }\end{array}$ & \\
\hline \multirow[t]{5}{*}{ Chemical decomposition } & Oxidation & Air & Corrosion \\
\hline & Electrical stress & Water & Impairment of heat transfer \\
\hline & Thermal stresses & Solid particles & Deterioration of electrical properties \\
\hline & & & Dielectric losses \\
\hline & & & Arcing \\
\hline
\end{tabular}


voltage and an acid value of vegetable oil which concluded that vegetable oil has superior oxidation stability compared to mineral oil.

\section{Test of Insulating Liquid}

While transformer in service, insulating oil is subjected to thermal, electrical and mechanical stresses. On the other hand, contaminations caused due to chemical reactions between windings and other solid insulation, which is catalyzed by high operating temperature. As a result, it loses its original properties, causing it ineffective for its main purpose after many years. Different reasons responsible for the deterioration of liquid insulation is given in Table 3 and different tests which are considered to ascertain the quality of insulating oil are listed in tabular form in Table 4.

\section{Dissolve Gas Analysis}

The analysis of different gases in insulating transformer oil to quantify and identify the dissolved combustible gases is called dissolved gas analysis (DGA). It is used as a specialized diagnostic test for the transformer internal health condition monitoring. ${ }^{29,30}$ Out of nearly 3000 hydrocarbon compounds of transformer insulating oil, only as many as seven gases are usually considered for diagnostic purposes. There are different methods used for predicting the health condition of transformer. ${ }^{31}$ Some of these methods are Roger's Ratio method, Duval Triangle method, IEC Ratio method, Key gas method and combustible gas method. ${ }^{32,33}$ The temperature range at which these individual gases are produced, causes of evolution, their solubility in transformer insulating oil and concentration are given in Table 5.

Table 4. Test of insulating liquid.

\begin{tabular}{|c|c|c|c|}
\hline Categories & Parameters & Indication/quality & Apparatus/methods \\
\hline \multirow[t]{10}{*}{ Physical Test } & \multirow[t]{4}{*}{ Appearance } & \multicolumn{2}{|l|}{ Clear, transparent oil: good oil } \\
\hline & & \multicolumn{2}{|l|}{$\begin{array}{l}\text { Cloudy or foggy appearance: indicates moisture } \\
\text { presence }\end{array}$} \\
\hline & & Greenish oil: indicates presence of copper salts & \multirow[t]{2}{*}{ With naked eye } \\
\hline & & Acrid smell: indicates presence of acid & \\
\hline & \multirow[t]{2}{*}{ Density } & Generally varies between 0.80 to 0.89 & \multirow[t]{2}{*}{ Density Hydrometer } \\
\hline & & Lower density indicates lower viscosity & \\
\hline & Viscosity & High viscosity: indicates low heat removal & Viscometer \\
\hline & Pour point & High pour point: indicates better-insulating oil & Cloud pour point apparatus \\
\hline & Flash point & High flash point: indicates better insulating oil & Pensky-Martens closed cap apparatus \\
\hline & Interfacial tension & Lower value of IFT: indicates better insulating oil & Tensiometer, Ring method, IFT apparatus \\
\hline \multirow[t]{7}{*}{ Chemical Test } & Neutralization number & $\begin{array}{l}\text { Low neutralization number: indicates minimum } \\
\text { electrical conduction, minimum metal corrosion, } \\
\text { maximum life of insulation }\end{array}$ & $\begin{array}{l}\text { Potassium hydroxide required in gram to neutralize } \\
\text { the acid }\end{array}$ \\
\hline & Water content & $\begin{array}{l}\text { High water value: indicates low dielectric strength, } \\
\text { high chemical deterioration of insulating paper }\end{array}$ & $\begin{array}{l}\text { Water content test apparatus, Karl Fisher titration } \\
\text { method }\end{array}$ \\
\hline & Sediment and sludge & $\begin{array}{l}\text { High sediment/sludge: indicates low electrical } \\
\text { property }\end{array}$ & With a naked eye \\
\hline & Corrosive sulfur & More sulfur: more corrosion of metal parts & $\begin{array}{l}\text { Degree of corrosion by copper in contact with oil } \\
\text { under measurement }\end{array}$ \\
\hline & Oxidation stability & $\begin{array}{l}\text { Low oxidation value: indicates low acid and sludge } \\
\text { formation, minimum electrical conduction, and } \\
\text { metal corrosion, high heat transfer }\end{array}$ & $\begin{array}{l}\text { Oxidation stability test vessel, oxidation stability } \\
\text { apparatus }\end{array}$ \\
\hline & Inhibitor content & $\begin{array}{l}\text { Inhibited oils deteriorate more slowly than } \\
\text { uninhibited oils }\end{array}$ & Di-tertiary butyl para-Cresol \\
\hline & SK value & $\begin{array}{l}\text { Volume of concentrated sulphuric acid on adding to } \\
\text { test sample }\end{array}$ & Bis: $335-1993$ test method \\
\hline \multirow[t]{3}{*}{ Electrical Test } & $\begin{array}{l}\text { Electric strength: } \\
\text { Breakdown voltage } \\
\text { (BDV) test }\end{array}$ & $\begin{array}{l}\text { Higher the BDV value: better the ability to withstand } \\
\text { electric stress }\end{array}$ & $\begin{array}{l}\text { Spherical and semi hemispherical brass electrodes } \\
\text { test arrangement }\end{array}$ \\
\hline & $\begin{array}{l}\text { Dielectric dissipation factor } \\
\quad(\tan \text { delta })\end{array}$ & $\begin{array}{l}\text { Lower dissipation factor: indicates better insulating } \\
\text { oil }\end{array}$ & $\begin{array}{l}\text { Measurement of phase difference between applied } \\
\text { voltage and resulting current }\end{array}$ \\
\hline & Resistivity & Higher resistivity: indicates better insulating oil & Automatic resistivity test set \\
\hline \multirow[t]{3}{*}{ Optical Test } & Oil level measurement & $\begin{array}{l}\text { Oil level proportional to output voltage, higher the } \\
\text { output voltage higher the oil level }\end{array}$ & $\begin{array}{l}\text { Continuous and discrete optical sensor-based } \\
\text { instrumentation system }\end{array}$ \\
\hline & Temperature measurement & Change of temperature proportional to output voltage & Optical sensor-based instrumentation system \\
\hline & Moisture measurement & $\begin{array}{l}\text { Amount of moisture in oil proportional to output } \\
\text { voltage }\end{array}$ & Optical sensor-based instrumentation system \\
\hline
\end{tabular}


Table 5. Dissolve gas analysis.

\begin{tabular}{|c|c|c|c|c|c|c|}
\hline \multirow[b]{2}{*}{ Gases } & \multirow[b]{2}{*}{ Evolution temperature } & \multirow[b]{2}{*}{ Nature of faults } & \multirow[b]{2}{*}{ Solubility coefficient } & \multicolumn{3}{|c|}{ Concentration (ppm) } \\
\hline & & & & $\begin{array}{l}\text { Less than } \\
\text { four years }\end{array}$ & $\begin{array}{c}\text { Between } \\
4 \text { to } 10 \text { years }\end{array}$ & $\begin{array}{l}\text { More than } \\
10 \text { years }\end{array}$ \\
\hline $\mathrm{H}_{2}$ & $\geq 150^{\circ} \mathrm{C}$ & Partial discharge, arcing in oil & 7 & $50-70$ & $100-150$ & $200-300$ \\
\hline $\mathrm{CH}_{4}$ & $150^{\circ} \mathrm{C}$ to $300^{\circ} \mathrm{C}$ & $\begin{array}{l}\text { Partial discharge in oil, } \\
\text { overheating of oil }\end{array}$ & 30 & $30-50$ & $100-150$ & $800-1000$ \\
\hline $\mathrm{C}_{2} \mathrm{H}_{6}$ & $250^{\circ} \mathrm{C}$ to $350^{\circ} \mathrm{C}$ & Overheating of oil & 280 & $100-150$ & $150-200$ & $200-400$ \\
\hline $\mathrm{C}_{2} \mathrm{H}_{4}$ & $350^{\circ} \mathrm{C}$ to $700^{\circ} \mathrm{C}$ & Overheating of oil & 280 & $20-30$ & $30-50$ & $150-200$ \\
\hline $\mathrm{C}_{2} \mathrm{H}_{2}$ & $\geq 700^{\circ} \mathrm{C}$ & Arcing in oil, overheating of oil & 400 & $100-150$ & $200-300$ & $300-400$ \\
\hline $\mathrm{CO}$ & $\geq 300^{\circ} \mathrm{C}$ & Cellulose overheating & 9 & $200-300$ & $400-500$ & $600-700$ \\
\hline $\mathrm{CO}_{2}$ & $\geq 300^{\circ} \mathrm{C}$ & Cellulose overheating & 120 & $3000-3500$ & $4000-5000$ & $9000-12000$ \\
\hline
\end{tabular}

\section{Properties of Alternative Transformer Insulating Liquid}

It has been found from the literature that most of the physical properties such as moisture content, flash point, dielectric strength, etc. of vegetable insulating oils are within the recommended level. Researchers are trying to bring the viscosity of coconut oil to recommended level by doing some chemical modification. Again, the pour point of coconut oil could be reduced to a considerable level by adding styrenated phenol to it. Besides the coconut oil, sunflower and rapeseed have excellent fire resistance and biodegradability properties. ${ }^{14}$ Comparison of typical values ${ }^{34}$ of different insulating properties has been given in Table 6. A large number of research works have been done by the researchers across the globe to find out an environment-friendly substitute of transformer mineral oil. Some findings of these research works are analyzed here. References 35-37 explained the performance of vegetable oil like coconut oil as an alternative to mineral oil in the transformer and compares the thermal aging of insulating paper in mineral oil with that of paper in vegetable oil over the specific temperature range. Yang $\mathrm{Xu}$ et al. ${ }^{38}$ investigated oxidation stability of vegetable transformer oil under accelerated thermal aging by using pressure differential scanning calorimetry (PDSC) method and draws the conclusion that acidity is not suitable but viscosity is responsive for vegetable oils. Imad-U-Khan et al. and Muhamad et al. ${ }^{39,40}$ adopt a new ratio criteria of dissolved gas analysis for fault detection and diagnosis and found that less amount of gases are produced in ester-based insulating liquid compared to mineral oil. References 41,42 and 43 studied the breakdown characteristics of coconut oils with mineral insulating oil. The results indicated that coconut oil has higher breakdown value than mineral oil. Ramli et al. and Arief et al. ${ }^{44,45}$ studied about the partial discharge characteristics of palm fatty acid ester (PFAE) and draws the conclusion that PFAE has good potential to be used as cooling and insulating liquid in power transformer. Hosier et $a l .{ }^{46}$ investigated biodegradable olive oil, rapeseed oil, crone and sunflower oil using ultraviolet/visible, infrared spectroscopes and found that olive oil offered excellent resistance to aging, rapeseed oil offered intermediate properties whereas corn and sunflower oil oxidized appreciably after aging. Nanayakkara et al. ${ }^{47}$ presented variations of capacitance and dielectric losses of coconut oil and mineral oil impregnated pressboard samples during oven heating using frequency domain dielectric spectroscopy (FDS) and draws the conclusion that losses were relatively higher for coconut oil impregnated pressboard samples in comparison to mineral oil.

Table 6. Comparison of electrical insulating liquids-typical values. ${ }^{28}$

\begin{tabular}{lccccc}
\hline Properties & Mineral oils & Silicone oils & Synthetic esters & Vegetable oils & Test method \\
\hline Dielectric breakdown, $\mathrm{kV}$ & $30-85$ & $35-60$ & $45-70$ & $82-97$ & IEC60156 \\
Relative permittivity at $25^{\circ} \mathrm{C}$ & $2.1-2.5$ & $2.6-2.9$ & $3.0-3.5$ & $3.1-3.3$ & IEC60247 \\
Viscosity at $0^{\circ} \mathrm{C}, \mathrm{mm}^{2} \mathrm{~s}^{-1}$ & -76 & $81-92$ & $26-50$ & $143-77$ & ISO3104 \\
Viscosity at $40^{\circ} \mathrm{C}, \mathrm{mm}^{2} \mathrm{~s}^{-1}$ & $3-16$ & $35-40$ & $14-29$ & $16-37$ & ISO3104 \\
Viscosity at $100^{\circ} \mathrm{C}, \mathrm{mm}^{2} \mathrm{~s}^{-1}$ & $2-2.5$ & $15-17$ & $4-6$ & $4-8$ & ISO3104 \\
Pour point, $0^{\circ} \mathrm{C}$ & -30 to -60 & -50 to -60 & -40 to -50 & -19 to -33 & ISO3016 \\
Flash point, $0^{\circ} \mathrm{C}$ & $100-170$ & $300-310$ & $250-270$ & $315-328$ & ISO2592(1) \\
Fire point, $0^{\circ} \mathrm{C}$ & $180-185$ & $340-350$ & $300-310$ & $350-360$ & ISO2592(1) \\
Density at $20^{\circ} \mathrm{C}, \mathrm{kg} \mathrm{dm}^{3}$ & $0.83-0.89$ & $0.96-1.10$ & $0.90-1.00$ & $0.87-0.92$ & ISO3675 \\
Specific heat, $\mathrm{J} \mathrm{g}^{-1} \mathrm{~K}^{-1}$ & $1.6-2.0$ & 1.5 & $1.8-2.3$ & $1.5-2.1$ & ASTME1269 \\
Thermal conductivity, $\mathrm{Wm}^{-1} \mathrm{~K}^{-1}$ & $0.11-0.16$ & 0.15 & 0.15 & $0.16-0.17$ & (DCS) \\
\hline
\end{tabular}


Table 7. Properties of new insulating oil filled in new power transformer as per IS 1866:2000.

\begin{tabular}{|c|c|c|c|}
\hline & Voltage level & Voltage level & Voltage level \\
\hline Properties & $>72.5 \mathrm{kV}$ & $72.5 \mathrm{kV}$ to $170 \mathrm{kV}$ & $>170 \mathrm{kV}$ \\
\hline Appearance & $\begin{array}{l}\text { Clear, sediment and } \\
\text { suspended matter free }\end{array}$ & $\begin{array}{l}\text { Clear, sediment and } \\
\text { suspended matter free }\end{array}$ & $\begin{array}{l}\text { Clear, sediment and } \\
\text { suspended matter free }\end{array}$ \\
\hline Density at $29^{\circ} \mathrm{C}, \mathrm{gm} / \mathrm{cm}^{3}$, Max & 0.89 & 0.89 & 0.89 \\
\hline Viscosity at $27^{\circ} \mathrm{C}, \mathrm{cSt}, \mathrm{Max}$ & 27 & 27 & 27 \\
\hline Flash point, ${ }^{\circ} \mathrm{C}$, Min & 140 & 140 & 140 \\
\hline Pour point, ${ }^{\circ} \mathrm{C}$, Max & -6 & -6 & -6 \\
\hline Neutralization value, $\mathrm{mg} \mathrm{KOH/g,} \mathrm{Max}$ & 0.03 & 0.03 & 0.03 \\
\hline Water content, ppm, Max & 20 & 15 & 10 \\
\hline Interfacial tension, $\mathrm{Mn} / \mathrm{m}, \mathrm{Min}$ & 35 & 35 & 35 \\
\hline $\mathrm{DDF}(\tan \delta)$ at $90^{\circ} \mathrm{C}, 40-60 \mathrm{~Hz}, \mathrm{Max}$ & 0.015 & 0.015 & 0.010 \\
\hline Resistivity at $90^{\circ} \mathrm{C} \times 10^{12} \mathrm{ohm}-\mathrm{cm}$, Min & 6 & 6 & 6 \\
\hline Breakdown Voltage, kV (rms), Min & 40 & 50 & 60 \\
\hline \multicolumn{4}{|c|}{ Oxidation stability of uninhibited oil: } \\
\hline Neutralization value, $\mathrm{mgKOH} / \mathrm{g}$, Max & 0.4 & 0.4 & 0.4 \\
\hline Sludge, Max & 0.1 & 0.1 & 0.1 \\
\hline
\end{tabular}

Table 8. Important work recently published in IEEE transaction.

\begin{tabular}{|c|c|c|c|c|}
\hline Sl.No. & Author/Year & Findings & $\begin{array}{l}\text { Involved instrumentation system/ } \\
\text { Technology }\end{array}$ & Comment \\
\hline 1 & $\begin{array}{l}\text { B. S. H. M. S. Y. } \\
\text { Matharage/2013 }\end{array}$ & $\begin{array}{l}\text { Coconut oil can be a good choice as } \\
\text { an alternative to the conventional } \\
\text { mineral oil for power transformers }\end{array}$ & $\begin{array}{l}\text { Frequency dielectric spectroscopy } \\
\text { measurement and using dissolved } \\
\text { gas analysis method }\end{array}$ & $\begin{array}{l}\text { This paper presents the performance of } \\
\text { coconut oil as an alternative of transformer } \\
\text { oil }\end{array}$ \\
\hline 2 & $\begin{array}{l}\text { Maria Augusta G. } \\
\text { Martins/2010 }\end{array}$ & $\begin{array}{l}\text { The use of the vegetable oil as an } \\
\text { insulating liquid is a very } \\
\text { promising option. }\end{array}$ & $\begin{array}{l}\text { Compare the vegetable oil-based } \\
\text { dielectric fluid Biotemp, and the } \\
\text { Kraft paper. }\end{array}$ & $\begin{array}{l}\text { This paper compares the thermal aging of } \\
\text { insulating paper in mineral oil with that of } \\
\text { paper in vegetable oil over the specific } \\
\text { temperature range }\end{array}$ \\
\hline 3 & S. Okabe/2013 & $\begin{array}{l}\text { Due to the aging, for example, of } \\
\text { about } 30 \text { years, properties of both } \\
\text { insulating oil and solid insulation } \\
\text { were degraded as a whole }\end{array}$ & $\begin{array}{l}\text { Based on volume resistivity, dielectric } \\
\text { loss, Interfacial, acid value }\end{array}$ & $\begin{array}{l}\text { In this paper, insulation degradation of shell- } \\
\text { type and core-type transformer has been } \\
\text { studied by aging }\end{array}$ \\
\hline 4 & H. Borsi/2005 & $\begin{array}{l}\text { Use of ester liquid midel } 7131 \\
\text { reduces the risk of environmental } \\
\text { pollution, increases the lifetime of } \\
\text { the component and reduces the fire } \\
\text { risk. }\end{array}$ & $\begin{array}{l}\text { Comparative study using ester liquid } \\
\text { midel } 7131\end{array}$ & $\begin{array}{l}\text { Presents a comparison of the performance of } \\
\text { natural and synthetic ester as an alternative } \\
\text { to mineral oil }\end{array}$ \\
\hline 5 & Yang Xu/2014 & $\begin{array}{l}\text { Acidity is not suitable but viscosity is } \\
\text { responsive for vegetable oils. }\end{array}$ & $\begin{array}{l}\text { Investigated by using Pressure } \\
\text { Differential Scanning Calorimetry } \\
\text { (PDSC) method }\end{array}$ & $\begin{array}{l}\text { This paper focuses on oxidation stability } \\
\text { assessment of a vegetable transformer oil } \\
\text { under accelerated thermal aging }\end{array}$ \\
\hline 6 & Imad-U-Khan/2007 & $\begin{array}{l}\text { Less amount of gases produces in } \\
\text { ester-based insulating liquid }\end{array}$ & $\begin{array}{r}\text { Dissolve gas analysis method on } \\
\text { ester-based transformer fluids }\end{array}$ & $\begin{array}{l}\text { Modified or new ratio criteria has to adapt for } \\
\text { fault detection and diagnosis }\end{array}$ \\
\hline 7 & N. A. Muhamad/2008 & $\begin{array}{l}\text { Validate the result based on existing } \\
\text { DGA fault interpretation methods }\end{array}$ & $\begin{array}{l}\text { Experimental tests performed on } \\
\text { laboratory models }\end{array}$ & $\begin{array}{l}\text { This paper explains about the investigation of } \\
\text { hydrocarbon gas products generated when } \\
\text { arcing happened }\end{array}$ \\
\hline 8 & S. Ranawana/2008 & $\begin{array}{l}\text { Breakdown value is considerably } \\
\text { higher than that of new mineral oil }\end{array}$ & $\begin{array}{l}\text { Measurements were carried out in } \\
\text { frequency domain at different } \\
\text { temperatures }\end{array}$ & $\begin{array}{l}\text { Stability of coconut oil as an insulating liquid } \\
\text { has been studied }\end{array}$ \\
\hline 9 & S. S. Sinan/2015 & $\begin{array}{l}\text { Palm oil and coconut oil have fairly } \\
\text { similar AC breakdown strength } \\
\text { and withstand voltages }\end{array}$ & $\begin{array}{l}\text { Comparative study of palm oil and } \\
\text { coconut oil with mineral oils }\end{array}$ & $\begin{array}{l}\text { The breakdown voltage of palm oil and } \\
\text { coconut oil are investigated }\end{array}$ \\
\hline
\end{tabular}


Table 8. (Continued)

\begin{tabular}{|c|c|c|c|c|}
\hline Sl.No. & Author/Year & Findings & $\begin{array}{l}\text { Involved instrumentation system/ } \\
\text { Technology }\end{array}$ & Comment \\
\hline 10 & A. A. H. Zaidi/2015 & $\begin{array}{l}\text { Virgin coconut oil has the highest } \\
\text { breakdown voltage, lowest } \\
\text { moisture content and also lowest } \\
\text { viscosity }\end{array}$ & $\begin{array}{l}\text { Comparative study of palm oil, } \\
\text { coconut oil, and virgin coconut oil } \\
\text { with mineral oils }\end{array}$ & $\begin{array}{l}\text { In this paper, palm oil, coconut oil and virgin } \\
\text { coconut oil are tested in a single-phase step } \\
\text { down transformer and induction motor as a } \\
\text { load }\end{array}$ \\
\hline 11 & Y. Z. Arief/2014 & $\begin{array}{l}\text { Both palm fatty acid ester and FR3 } \\
\text { oils have a lower value of the } \\
\text { dielectric dissipation factor and } \\
\text { higher value of capacitance }\end{array}$ & $\begin{array}{l}\text { Analyzed using computational } \\
\text { simulation to investigate the } \\
\text { dielectric characteristic }\end{array}$ & $\begin{array}{l}\text { A comparative study on the effect of electrical } \\
\text { aging on electrical properties of palm fatty } \\
\text { acid ester and FR3 has been discussed }\end{array}$ \\
\hline 12 & M. R. Ramli/2014 & $\begin{array}{l}\text { Palm fatty acid ester (PFAE) has a } \\
\text { good potential to be used as a } \\
\text { power transformer oil }\end{array}$ & $\begin{array}{l}\text { Comparative study of PFAE with } \\
\text { mineral oils }\end{array}$ & $\begin{array}{l}\text { Partial discharge characteristics of palm fatty } \\
\text { acid ester has been studied }\end{array}$ \\
\hline 13 & I. L. Hosier/2011 & $\begin{array}{l}\text { Olive oil offered excellent resistance } \\
\text { to aging, rapeseed oil offered } \\
\text { intermediate properties whereas } \\
\text { corn and sunflower oil oxidized } \\
\text { appreciably after aging }\end{array}$ & $\begin{array}{l}\text { Used ultraviolet/visible, infrared and } \\
\text { dielectric spectroscopies }\end{array}$ & $\begin{array}{l}\text { Aging of biodegradable oils and assessment of } \\
\text { their suitability for high voltage } \\
\text { applications has been studied }\end{array}$ \\
\hline 14 & $\begin{array}{l}\text { N. W. N. J. } \\
\text { Nanayakkara/2013 }\end{array}$ & $\begin{array}{l}\text { Losses were relatively higher for } \\
\text { coconut oil impregnated } \\
\text { pressboard samples in comparison } \\
\text { to mineral oil. }\end{array}$ & $\begin{array}{l}\text { The dielectric properties were } \\
\text { obtained by FDS measurements }\end{array}$ & $\begin{array}{l}\text { This paper presents variations of capacitance } \\
\text { and dielectric losses of coconut oil and } \\
\text { mineral oil impregnated pressboard } \\
\text { samples during oven heating }\end{array}$ \\
\hline
\end{tabular}

\section{Properties of New Insulating Oil Filled in New Power Transformer as per IS 1866:2000}

Properties of unused new insulating oil filled in new power transformer differ from that of new insulating oil. The new insulating oil when filled in power transformer comes in contact with different construction materials and other solid insulating materials and gets contaminated and changes its properties. These changes of properties depend upon the types of materials used for construction and ratios of solid to liquid insulation, and should be kept within acceptable limits adapting proper processing techniques and proper selection of materials. Power transformers need testing of liquid insulation before energizing the transformer. Indian standard recommended limits are given in Table 7. Some papers published in IEEE transaction is listed in Table 8.

\section{Conclusion}

The nonrenewable mineral oil used in power transformer is nonbiodegradable and it can be potentially hazardous to the environment. Researchers are looking for the alternatives which are derived from renewable and environmentally friendly sources. This review paper explains about the physical, chemical and electrical characteristics and the various deterioration reasons of the liquid insulation used in the transformer. As per literature survey, research in recent years on alternate insulating oil clearly draws the following points:

(1) Virgin Coconut oil can be a good choice as an alternative to the conventional mineral oil for power transformers. It has the highest breakdown voltage, lowest viscosity and lowest moisture content compare to palm oil and other renewable insulating oil.

(2) Vegetable oil which can be used as one of the alternatives to replace mineral oils in transformers is suitable to be used in sealed transformers.

(3) The rate of production of dissolved gases in esters during thermal and electrical faults is less in comparison with petroleum-based mineral oil. Esters are predominantly stable under particular temperature range thermal faults.

(4) Acetylene is mainly responsible for electrical fault for low energy discharges and hydrogen is the key fault indicating gas for partial discharges.

(5) Partial discharge magnitudes of palm fatty acid ester (PFAE) are slightly lower than those of petroleum-based mineral oil during the aging time. Therefore, palm fatty acid ester has a good potential to be used as power transformer oil in electrical power system application.

\section{References}

${ }^{1}$ M. Wang, A. J. Vandermaar and K. D. Srivastava, Review of condition assessment of power transformers in service, IEEE Electr. Insul. Mag. 18(6), 12 (2002).

${ }^{2}$ D. Arvind, S. Khushdeep and K. Deepak, Condition monitoring of power transformer: A review, 2008 IEEE/PES Transmission and Distribution Conf. Exposition (April, 2008), pp. 1-6.

${ }^{3}$ B. Pahlavanpour and A. Wilson, Analysis of transformer oil for transformer condition monitoring, IEE Colloquium on An Engineering Review Liquid Insulation (Digest No. 1997/003) (Jan 1997), pp. 1/1-1/5. 
${ }^{4}$ J. H. Harlow, Electric power transformer engineering - Book review, IEEE Electr. Insul. Mag. 20(3), 64 (2004).

${ }^{5}$ S. P. Balaji, I. P. M. Sheema, G. Krithika and S. Usa, Effect of repeated impulses on transformer insulation, IEEE Trans. Dielectr. Electr. Insul. 18(6), 2069 (2011).

${ }^{6}$ A. A. Pollitt, Mineral oils for transformers and switchgear, J. Inst. Electr. Eng. Gen. 89(20), 366 (1942).

${ }^{7}$ M. S. Dharwadkar and J. J. Patel, Development of mixed dielectrics for high voltage power capacitors using mineral oil, in 1979 EIC 14th Electrical/Electronics Insulation Conf. (Oct, 1979), pp. 246-249.

${ }^{8}$ L. Dix and P. J. Hopkinson, Tapchangers for de-energized operation in natural ester fluid, mineral oil and silicone, in 2009 IEEE Power Energy Society General Meeting (July, 2009), pp. 1-6.

${ }^{9}$ H. P. Gasser, C. Krause, M. Lashbrook and R. Martin, Aging of pressboard in different insulating liquids, in 2011 IEEE Int. Conf. Dielectric Liquids (June, 2011), pp. 1-5.

${ }^{10}$ I. Fofana, 50 years in the development of insulating liquids, IEEE Electr. Insul. Mag. 29(5), 13 (2013).

${ }^{11}$ J. Fabian, B. Wieser, M. Muhr, R. Schwarz, G. J. Pukel and M. Stssl, Partial discharge behavior of environmentally friendly and hardly inflammable ester liquids compared to mineral oil for power transformers, 2012 Int. Conf. Condition Monitoring and Diagnosis (CMD) (Sept, 2012), pp. 621-624.

${ }^{12}$ D. M. Mehta, P. Kundu, A. Chowdhury, V. K. Lakhiani and A. S. Jhala, A review on critical evaluation of natural ester vis-a-vis mineral oil insulating liquid for use in transformers: Part 1, IEEE Trans. Dielectr. Electr. Insul. 23(2), 873 (2016).

${ }^{13}$ K. Bandara, C. Ekanayake and T. K. Saha, Comparative study for understanding the behaviour of natural ester with mineral oil as a transformer insulating liquid, in 2014 IEEE Conf. Electrical Insulation and Dielectric Phenomena (CEIDP) (Oct, 2014), pp. 792-795.

${ }^{14}$ J. Ulrych, M. Svoboda, R. Polansk and J. Pihera, Dielectric analysis of vegetable and mineral oils, in 2014 IEEE 18th Int. Conf. Dielectric Liquids (ICDL) (June, 2014), pp. 1-4.

${ }^{15}$ Suwarno and Santosh, Effects of electric arc on discharge inception, combustible gases and chemical structure of transformer oils, 2012 Int. Conf. Power Engineering and Renewable Energy (ICPERE) (July, 2012), pp. 1-4.

${ }^{16}$ L. S. Mohammed, Mazood, M. Bakrutheen, M. Willjuice, Iruthayarajan and M. Karthik, Studies on critical properties of vegetable oil based insulating fluids, in 2015 Annual IEEE India Conf. (INDICON) (Dec, 2015), pp. 1-4.

${ }^{17} \mathrm{P}$. Thomas, Biodegradable dielectric liquids for transformer applications, Proc. 2005 Int. Symp. Electrical Insulating Materials, 2005 (ISEIM 2005), Vol. 1 (June, 2005), pp. 135-136.

${ }^{18}$ C. C. Claiborne, E. J. Walsh and T. V. Oommen, An agriculturally based biodegradable dielectric fluid, in 1999 IEEE Transmission and Distribution Conf., Vol. 2 (Apr, 1999), pp. 876-881.

${ }^{19}$ I. V. Timoshkin, M. J. Given, M. P. Wilson and S. J. MacGregor, Review of dielectric behaviour of insulating liquids, 2009 Proc. 44th Int. Universities Power Engineering Conference (UPEC) (Sept, 2009), pp. 1-4.

${ }^{20} \mathrm{M}$. George and P. Manikandan, Dielectric performance of solid dielectric immersed in vegetable oil with antioxidant, 2016 Int. Conf. Circuit, Power and Computing Technologies (ICCPCT) (March, 2016), pp. 1-7.

${ }^{21} \mathrm{~T}$. V. Oommen, Vegetable oils for liquid-filled transformers, IEEE Electr. Insul. Mag. 18(1), 6 (2002).
${ }^{22}$ Q. Liu, Z. D. Wang and F. Perrot, Impulse breakdown voltages of ester-based transformer oils determined by using different test methods, IEEE Conf. Electrical Insulation and Dielectric Phenomena, 2009 (CEIDP'09) (Oct, 2009), pp. 608-612.

${ }^{23} \mathrm{~S}$. Okabe, S. Kaneko, M. Kohtoh and T. Amimoto, Analysis results for insulating oil components in field transformers, IEEE Trans. Dielectr. Electr. Insul. 17(1), 302 (2010).

${ }^{24} \mathrm{~S}$. Tenbohlen and M. Koch, Aging performance and moisture solubility of vegetable oils for power transformers, IEEE Trans. Power Deliv. 25(2), 825 (2010).

${ }^{25}$ D. Divakaran and C. Kalaivanan, Investigation of lightning impulse voltage characteristics and other thermo-physical characteristics of vegetable oils for power apparatus applications, in 2012 IEEE 10th Int. Conf. Properties and Applications of Dielectric Materials (July, 2012), pp. 1-4.

${ }^{26}$ P. Guo, R. Liao, J. Hao, Z. Ma and L. Yang, Research on the temperature dielectric spectrum of vegetable oil, mineral oil and their relevant oil-impregnated papers, in 2012 Int. Conf. High Voltage Engineering and Application (Sept, 2012), pp. 562-565.

${ }^{27}$ T. Kanoh, H. Iwabuchi, Y. Hoshida, J. Yamada, T. Hikosaka, A. Yamazaki, Y. Hatta and H. Koide, Analyses of electro-chemical characteristics of palm fatty acid esters as insulating oil, 2008 IEEE Int. Conf. Dielectric Liquids (June, 2008), pp. 1-4.

${ }^{28}$ Y. Bertrand and L. C. Hoang, Vegetal oils as substitute for mineral oils, Proc. 7th Int. Conf. Properties and Applications of Dielectric Materials (Cat. No. 03CH37417), Vol. 2 (June, 2003), pp. 491-494.

${ }^{29} \mathrm{~B}$. Song and Z. Peng, Research of the fga-ann method for transformer fault diagnosis based on the dissolved gas analysis, Fifth World Congress Intelligent Control and Automation, 2004 (WCICA 2004), Vol. 6 (2004), pp. 5145-5149.

${ }^{30}$ A. K. Mehta, R. N. Sharma, S. Chauhan and S. Saho, Transformer diagnostics under dissolved gas analysis using support vector machine, in 2013 Int. Conf. Power, Energy and Control (ICPEC) (Feb, 2013), pp. 181-186.

${ }^{31}$ M. R. Ahmed, M. A. Geliel and A. Khalil, Power transformer fault diagnosis using fuzzy logic technique based on dissolved gas analysis, 2013 21st Mediterranean Conf. Control Automation (MED) (June, 2013), pp. 584-589.

${ }^{32}$ N. A. Setiawan, Sarjiya and Z. Adhiarga, Power transformer incipient faults diagnosis using dissolved gas analysis and rough set, 2012 Int. Conf. Condition Monitoring and Diagnosis (CMD) (Sept, 2012), pp. 950-953.

${ }^{33}$ J. J. Kelly, Transformer fault diagnosis by dissolved-gas analysis, IEEE Trans. Ind. Appl. IA-16(6), 777 (1980).

${ }^{34}$ B. S. H. M. S. Y. Matharage, M. A. R. M. Fernando, M. A. A. P. Bandara, G. A. Jayantha and C. S. Kalpage, Performance of coconut oil as an alternative transformer liquid insulation, IEEE Trans. Dielectr. Electr. Insul. 20(3), 887 (2013).

${ }^{35}$ M. A. G. Martins, Vegetable oils, an alternative to mineral oil for power transformers - experimental study of paper aging in vegetable oil versus mineral oil, IEEE Electr. Insul. Mag. 26(6), 7 (2010).

${ }^{36} \mathrm{~S}$. Okabe, G. Ueta and T. Tsuboi, Investigation of aging degradation status of insulating elements in oil-immersed transformer and its diagnostic method based on field measurement data, IEEE Trans. Dielectr. Electr. Insul. 20(1), 346 (2013).

${ }^{37}$ H. Borsi and E. Gockenbach, Properties of ester liquid midel 7131 as an alternative liquid to mineral oil for transformers, IEEE Int. Conf. Dielectr. Liquids (ICDL 2005) (June, 2005), pp. 377-380. 
${ }^{38}$ Y. Xu, S. Qian, Q. Liu and Z. D. Wang, Oxidation stability assessment of a vegetable transformer oil under thermal aging, IEEE Trans. Dielectr. Electr. Insul. 21(2), 683 (2014).

${ }^{39}$ Imad-U-Khan, Z. Wang, I. Cotton and S. Northcote, Dissolved gas analysis of alternative fluids for power transformers, IEEE Electr. Insul. Mag. 23(5), 5 (2007).

${ }^{40}$ N. A. Muhamad, B. T. Phung and T. R. Blackburn, Dissolved gas analysis (DGA) of arcing faults in biodegradable oil insulation systems, 2008 Int. Symp. Electrical Insulating Materials, 2008 (ISEIM 2008) (Sept, 2008), pp. 24-27.

${ }^{41}$ S. Ranawana, C. M. B. Ekanayaka, N. A. S. A. Kurera, M. A. R. M. Fernando and K. A. R. Perera, Analysis of insulation characteristics of coconut oil as an alternative to the liquid insulation of power transformers, in 2008 IEEE Region 10 and the Third Int. Conf. Industrial and Information Systems (Dec, 2008), pp. 1-5.

${ }^{42}$ S. S. Sinan, J. Jasni, N. Azis, M. Z. A. A. Kadir and M. N. Mohtar, Assessment on the AC breakdown voltages of liquid insulation system, 2015 IEEE Int. Circuits and Systems Symp. (ICSyS) (Sept, 2015), pp. 155-158.

${ }^{43}$ A. A. H. Zaidi, N. Hussin and M. K. M. Jamil, Experimental study on vegetable oils properties for power transformer, 2015 IEEE Conf. Energy Conversion (CENCON) (Oct, 2015), pp. 349-353.
${ }^{44}$ Y. Z. Arief, M. H. Ahmad, K. Y. Lau, N. A. Muhamad, N. Bashir, N. K. Mohd, L. W. Huey, Y. S. Kiat and S. A. Azli, A comparative study on the effect of electrical ageing on electrical properties of palm fatty acid ester (PFAE) and fr3 as dielectric materials, 2014 IEEE Int. Conf. Power and Energy (PECon) (Dec, 2014), pp. $128-133$.

${ }^{45}$ M. R. Ramli, Y. Z. Arief, S. A. Azli, N. A. Muhamad, K. Y. Lau, M. Farhan, N. Bashir, N. K. Mohd, L. W. Huey and Y. S. Kiat, Partial discharge characteristics of palm fatty acid ester (PFAE) as high voltage insulating material, 2014 Int. Conf. Power Engineering and Renewable Energy (ICPERE) (Dec, 2014), pp. 262266.

${ }^{46}$ I. L. Hosier, A. Guushaa, E. W. Westenbrink, C. Rogers, A. S. Vaughan and S. G. Swingler, Aging of biodegradable oils and assessment of their suitability for high voltage applications, IEEE Trans. Dielectr. Electr. Insul. 18(3), 728 (2011).

${ }^{47}$ N. W. N. J. Nanayakkara, K. P. Madubhashini, P. Y. C. D. Samarajeewa, M. A. R. M. Fernando, J. R. S. S. Kumara and C. S. Kalpage, Dielectric properties of coconut oil impregnated pressboard samples, 2013 IEEE 8th Int. Conf. Industrial and Information Systems (Dec, 2013), pp. 179-184. 